\title{
Yellow head virus from Thailand and gill-associated virus from Australia are closely related but distinct prawn viruses
}

\author{
Jeff A. Cowley ${ }^{1, *}$, Christine M. Dimmock ${ }^{1}$, Chainarong Wongteerasupaya ${ }^{2}$, Vichai Boonsaeng ${ }^{3}$, \\ Sakol Panyim ${ }^{3}$, Peter J. Walker ${ }^{1}$
}

\author{
${ }^{1}$ CRC for Aquaculture, CSIRO Tropical Agriculture, PMB 3, Indooroopilly 4068, Australia \\ ${ }^{2}$ Department of Biochemistry, Faculty of Medicine, Srinakharinwirot University, Sukhumvit 23, Bangkok 10110, Thailand \\ ${ }^{3}$ Department of Biochemistry, Faculty of Science, Mahidol University, Rama VI Road, Bangkok 10400, Thailand
}

\begin{abstract}
Corresponding genomic regions of isolates of yellow head virus (YHV) from Thailand and gill-associated virus (GAV) from Australia were compared by RT-PCR and sequence analysis. PCR primers designed from sequences in the GAV ORF1b polyprotein gene amplified the corresponding 577 nucleotide region of the YHV genome. Comparison of the amplified region indicated $85.1 \%$ nucleotide and $95.8 \%$ amino acid sequence identity. YHV PCR primers designed to amplify a 135 nucleotide product previously described as a YHV diagnostic probe failed to amplify the corresponding product from GAV RNA. However, the cognate GAV sequence for this and another recently reported YHV sequence were located in an upstream region of the ORF1b gene. A comparison of these sequences indicated identities of 83.0 and $80.9 \%$ at the nucleotide level and 86.7 and $86.5 \%$ at the amino acid level, respectively. The data indicate that GAV and YHV are closely related but distinct viruses for which differential diagnostic probes can be applied.
\end{abstract}

KEY WORDS: Yellow head virus (YHV) - Gill-associated virus (GAV) - Lymphoid organ virus (LOV) - Penaeus monodon RT-PCR - Sequence analysis

Yellow head virus (YHV) was first reported to be associated with mass mortalities of farmed Penaeus monodon (black tiger prawns) in Thailand in 1990 (Limsuwan 1991). The disease affects juvenile to subadult prawns and is usually characterised by a pale to yellowish colouration of the cephalothorax and gills, and erratic swimming of infected animals near the surface at the pond edge. Enveloped, rod-shaped virions and helical nucleocapsids are observed by transmission electron microscopy in the cytoplasm of infected haemocytes, lymphoid organ and gill cells (Boonyaratpalin et al. 1993, Chantanachookin et al. 1993). In

•E-mail: jeff.cowley@tag.csiro.au
1994, a similar virus was identified in healthy wild and farmed $P$. monodon in Queensland, Australia (Spann et al. 1995). Virions and nucleocapsids were morphologically indistinguishable from $\mathrm{YHV}$, but as they were observed exclusively within abnormal cell foci in the lymphoid organ, it was named lymphoid organ virus (LOV). In 1995-96, mass mortalities of juvenile and subadult $P$. monodon at 4 farms in north and southeast Queensland led to the identification of another similar virus (Spann et al. 1997). In this case, the lymphoid organ of diseased prawns displayed extensive structural degeneration and cellular necrosis and contained large numbers of helical nucleocapsids and rod-shaped virions that were indistinguishable from YHV. The disease was transmitted experimentally to healthy $P$. monodon and, in both naturally and experimentally infected $P$. monodon, histopathology resembled that of YHV infection. However, mortality was preceded by varying degrees of red body colouration and there was no indication of pale body colouration or yellowing of the cephalothorax as described for YHV. Unlike the non-pathogenic LOV, high infection levels were observed in gills as well as lymphoid organs and the pathogenic virus was named gill-associated virus (GAV; Spann et al. 1997). In Taiwan, a yellow headlike virus has also been identified in farmed $P$. japonicus (kuruma prawns) displaying typical signs of severe white spot disease (Wang et al. 1996). Although histopathology was characteristic of $\mathrm{YHV}$, its involvement in clinical disease was complicated by the likely coexistence of white spot syndrome virus.

Little is known of the molecular structure or the relationship between these yellow head-like viruses. Analyses of purified YHV preparations have indicated that virions contain a single-stranded RNA genome (Wongteerasupaya et al. 1995) and 4 major structural proteins of $\sim 170,135,67$ and $22 \mathrm{kDa}$ (Nadala et al. 
1997). The $135 \mathrm{kDa}$ protein was shown to be glycosylated (Nadala et al. 1997). Based on a rod-shaped virion morphology similar to plant rhabdoviruses and preliminary data suggesting that the large $(\sim 22 \mathrm{~kb})$ ssRNA genome may be of negative polarity, YHV has been provisionally proposed to be a member of the Rhabdoviridae (Loh et al. 1997, Nadala et al. 1997). However, we have recently determined the nucleotide sequence of a $9.1 \mathrm{~kb}$ region of the GAV genome which encodes a long open reading frame (ORF) with significant homologies in the functional domains of ORF1b polyproteins of arteri-, toro- and coronaviruses (Cowley et al. unpubl.). In addition to the ORF1b (replicase) gene, the genomic region contains a ribosomal frameshift site and intergenic promoter elements indicating that the replication mechanism employed by GAV is related to these positive-strand ssRNA viruses. In this paper, we report sequence relationships between YHV and GAV based on 3 regions of the large ORF1b gene.

Materials and methods. cDNA library preparation: A GAV cDNA library was prepared by random amplification (Froussard 1992) of a $\sim 22 \mathrm{kbp}$ dsRNA replicative intermediate purified from lymphoid organ total RNA of Penaeus monodon infected experimentally with GAV as described previously (Spann et al. 1997). Briefly, 200 to $400 \mu \mathrm{g}$ total RNA isolated using TRIzolLS $^{\text {TM }}$ (Gibco-BRL) was resolved in a $0.6 \%$ low melting point agarose-TAE gel containing $0.5 \mu \mathrm{g} \mathrm{ml}^{-1}$ ethidium bromide (Sambrook et al. 1989). A $-22 \mathrm{kbp}$ dsRNA band was isolated using $\beta$-agarase (Boehringer Mannheim) digestion according to the manufacturer's instructions. dsRNA $(-10 \mathrm{ng})$ was strand-separated in the presence of $150 \mathrm{ng}$ uni-primer-dN $\mathrm{d}_{6}\left(5^{\prime}\right.$-GCCGGAGCTCTGCAGAATTC $\left(\mathrm{N}_{6}\right)^{-3^{\prime}}$ ) (Froussard 1992) by incubation in $12 \mu \mathrm{l} 8 \%$ deionised formamide in DEPC-water at $98^{\circ} \mathrm{C}$ for $8 \mathrm{~min}$ followed by rapid quenching on dry ice. Representative sequences were randomly amplified using the rPCR method described by Froussard (1992) except that $200 \mathrm{U}$ Superscript II (Gibco-BRL) was substituted for $20 \mathrm{U}$ AMV reverse transcriptase for first strand cDNA synthesis and that Taq DNA polymerase (Promega) was used in place of AmpliTaq (Perkin Elmer-Cetus). IPCR products were purified using a QIAquick ${ }^{\text {TM }}$ column (QIAGEN) and cloned by ligation into pGEM-T Vector (Promega) and transformation of competent E. coli DH5- $\alpha$ host cells (GibcoBRL). Plasmids containing inserts were purified from colonies selected with ampicillin, X-gal and IPTG as described by Sambrook et al. (1989).

Primers and PCR reactions: PCR primers GAV1 (5'-ATCCATACTACTCTAAACTTCC-3'), GAV2 (5'GAATTTCTCGAACAACAGACG-3'), GAV5 (5'-AACTTTGCCATCCTCGTCAC-3') and GAV6 (5' -TGGATGTTGTGTGTTCTCAAC-3') were designed to a $781 \mathrm{bp}$ cDNA clone (pG12) that contained a continuous long open reading frame (ORF) and were synthesized using an Oligo-1000 DNA Synthesizer (Beckman). Total RNA was extracted from the lymphoid organs of Penaeus monodon infected experimentally with YHV using TRIzol-LS ${ }^{\text {TM }}$ reagent (Gibco-BRL). For RT-PCR reactions, $10 \mathrm{ng}$ total RNA and 30 pmol each primer GAV5 and GAV6 were added to a reaction mixture comprising $10 \mathrm{mM}$ Tris- $\mathrm{HCl}, \mathrm{pH} 8.3,50 \mathrm{mM} \mathrm{KCl}, 1 \mathrm{U}$ ribonuclease inhibitor (Gibco-BRL), $2 \mathrm{mM} \mathrm{MgCl}_{2}, 200 \mu \mathrm{M}$ each dATP, dTTP, dCTP and dGTP, $200 \mathrm{U}$ Superscript II reverse transcriptase (Gibco-BRL) and $2.5 \mathrm{U}$ Taq DNA polymerase (Gibco-BRL). The mixture was incubated in a thermal cycler using 1 cycle of $42^{\circ} \mathrm{C}$ for $30 \mathrm{~min}, 94^{\circ} \mathrm{C}$ for $2 \mathrm{~min}$ followed by 30 cycles of $94^{\circ} \mathrm{C}$ for $15 \mathrm{~s}, 52^{\circ} \mathrm{C}$ for $15 \mathrm{~s}$ and $72^{\circ} \mathrm{C}$ for $15 \mathrm{~s}$ and a final elongation step of $72^{\circ} \mathrm{C}$ for $5 \mathrm{~min}$. For nested PCR, $0.5 \mu \mathrm{l}$ of the primary RT-PCR was amplified with the primer pair GAV1-2 using the conditions above but with reduced (i.e. 20) amplification cycles. PCR products were resolved in a $2 \%$ agarose-TAE gel containing $0.5 \mu \mathrm{g} \mathrm{ml}^{-1}$ ethidium bromide and visualized using a UV transilluminator. The 618 bp YHV PCR product was purified using a QIAquick ${ }^{\text {TM }}$ column (QIAGEN) and cloned by ligation into pGEM-T Vector (Promega) as described above.

Sequence analyses: Both DNA strands of the $618 \mathrm{bp}$ inserts in $3 \mathrm{YHV}$ PCR clones were sequenced using universal pUC forward and reverse primers, ThermoSequenase $^{\mathrm{TM}}$ (Amersham) and automated ABI Model377 sequencing systems (Applied Biosystems Inc.) at the Australian Genome Reference Facility, University of Queensland. Nucleotide sequence translations were performed using MacVector 3.5 software. Sequence alignments and estimations of sequence identity were conducted using Clustal W software at the Australian National Genomic Information Service at the University of Sydney. Sequences reported in this paper are deposited in the EMBL/GenBank database under Accession Numbers AF102827, AF102828, AF102829 and AF126718.

Results and discussion. The relationship between the morphologically and clinically related YHV from Thailand and GAV from Australia was determined by sequence comparison of 3 genomic regions located in the ORF1b-like gene. The first 618 nucleotide region was amplified from YHV RNA by RT-PCR using primers (GAV5 and GAV6) designed from a sequence overlapping the putative helicase domain of GAV ORF1b (Fig. 1). The authenticity of the YHV PCR product was confirmed by nested PCR amplification of an internal $317 \mathrm{bp}$ product using primers GAV1 and GAV2. The nucleotide and deduced amino acid sequences of the $618 \mathrm{bp} \mathrm{YHV} \mathrm{amplicon} \mathrm{were} \mathrm{determined}$ from the consensus of 3 clones and compared with the corresponding GAV sequence (Fig. 2a). In each virus, 


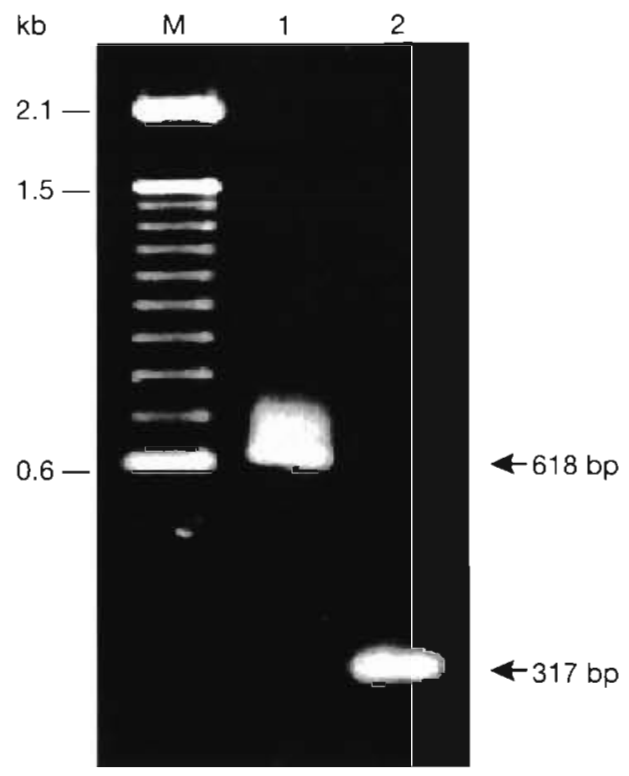

Fig. 1. Products of RT-PCR and nested PCR amplification of YHV RNA present in total lymphoid organ RNA isolated from YHV-infected Penaeus monodon. Total RNA (10 ng) was amplified by RT-PCR with the primer pair GAV5-6 using 30 cycles at an anneal temperature of $52^{\circ} \mathrm{C}$ (lane 1). An aliquot $(0.5 \mu \mathrm{l})$ of the RT-PCR was re-amplified by nested PCR with the primer pair GAV1-2 using 20 cycles and the same conditions (lane 2). PCR products were resolved in a $2 \%$ agarose/TAE containing $0.5 \mu \mathrm{g} \mathrm{ml}^{-1}$ ethidium bromide. $M$ represents a $100 \mathrm{bp}$ DNA ladder marker (Gibco-BRL)

the region encodes a continuous open reading frame (ORF). In the 577 bp region internal to primers GAV5 and GAV6, there was $85.1 \%$ identity in nucleotide sequence and $95.8 \%$ identity in amino acid sequence. The majority (77/86) of nucleotide mismatches modified codons in 'wobble' positions and were silent. Most amino acid substitutions (6/8) were conservative as defined by charge and polarity conservation and matching of aromatic residues (Poch et al. 1990).

A second comparison was conducted with the GAV genomic region corresponding to the $135 \mathrm{bp}$ sequence of a cDNA clone pMUY412 (Fig. 2b) used to establish a YHV diagnostic RT-PCR (Wongteerasupaya et al. 1997). In each virus, the region encodes a continuous ORF which is located towards the $5^{\prime}$ end of the GAV ORF1b gene (Fig. 3). Nucleotide sequence identity $(83.0 \%)$ was similar to that observed for the downstream 577 nucleotide region. However, amino acid sequence identity $(86.7 \%)$ was somewhat lower due to a higher proportion of codon changes in the first and second base positions. Significantly, there was considerable divergence between the GAV and YHV sequences in the terminal regions of the 135 nucleotide sequence targeted by YHV RT-PCR primers $10 \mathrm{~F}(6 / 20$ mismatches) and 144R (10/20 mismatches). Four of these mismatches occur at the extreme $3^{\prime}$-terminus of primer 144R. As would be expected from this level of mismatch, all attempts to amplify the corresponding 135 bp product from GAV using these YHV primers have failed (data not shown).

A 1068 nucleotide region of a YHV sequence recently reported by Tang \& Lightner (1999) was also analyzed. This sequence aligned with the GAV ORF1b gene upstream of and overlapping the 135 nucleotide sequence encompassed by the Thai primer pair 10F/144R (Wongteerasupaya et al. 1997). Although there appears to be an insertion error at $G^{408}$ which results in premature termination of the reading frame, the corrected sequence (excluding the overlap) shared $80.9 \%$ nucleotide and $86.5 \%$ amino acid sequence identity to GAV (Fig. 2c). A comparison of all 3 ORF1b regions, the relative positions of which are shown in Fig. 3, indicates that the overlapping 5 ' regions shared similar levels of sequence identity that were somewhat lower than that identified in the $3^{\prime}$ helicase region, particularly at the amino acid level. In the helicase region amplified by primers GAV5 and GAV6, the level of sequence divergence between YHV and GAV is similar to that observed within the same region of different strains (A59 and JHM) of murine coronaviruses (Bredenbeek et al. 1990, Lee et al. 1991). Moreover, the ORF1b gene is likely to be more highly conserved than other genes encoding structural proteins, especially in those domains of ORF1b associated with enzymatic activity.

The sequence comparisons reported here support clinical, histological and morphological observations suggesting that GAV from Australia and YHV from Thailand are closely related viruses (Boonyaratpalin et al. 1993, Chantanachookin et al. 1993, Spann et al. 1997). However, the level of sequence divergence between YHV and GAV is far greater than between individual Australian isolates of GAV which share $>98.5 \%$ identity at the nucleotide level (Cowley et al. unpubl.j. This indicates that YHV and GAV represent distinct genetic lineages and may be considered as different species or different geographic topotypes.

Regional and international movements of live and frozen shrimp provide opportunities for the inadvertent introduction of exotic pathogens and evidence has recently been reported for an incursion of YHV into the prawn aquaculture industry in the Americas via frozen commodity shrimp (Lightner et al. 1997, Nunan et al. 1998). Sequence analysis of yellow head-like viruses from various regions in Australasia, India and the Americas will be required to determine the extent of molecular diversity among isolates from these distinct geographical locations. Such molecular data and comparative pathological studies will be useful in epi- 
a) AACTTGCCATCCTCGTCACCCACCATGAAGCATTCTCAATCATCAGACAATATTTCACCGACATCGACATACAAATCCCAATCTACACTGTTCACACCTCCCAGGGCAGAACATTCGAT $\mathrm{N} F$ A I L V T H H E A F S I I R Q Y F T D I D I Q I P I Y T V H T S Q G R T F D 40

the GGTGGTATCGTCOTCAGCTATCGTAACACCGCCTTCACAAGGGATCCTAACATCGTCAACGTAGCTGTCAGCCGCTTCCGCTTCCAATGTATCTGCATGCACCAGGGTAATCCATACTAC 240 R G I V V S Y R N T A E I R D P N I V N $Y$ A V S R F R F Q C I C M H Q G N P Y Y BO

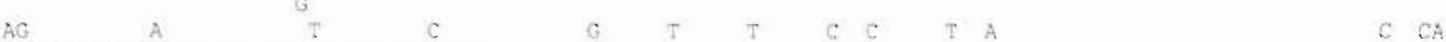

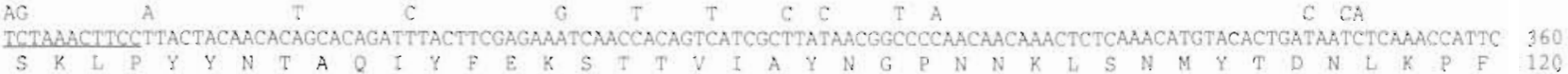

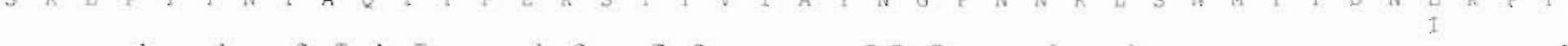

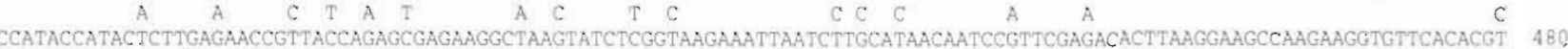
P Y H T L E N R Y Q S E K A K Y L G K K L I L H N N P F E T L K E A R K V F T R 160

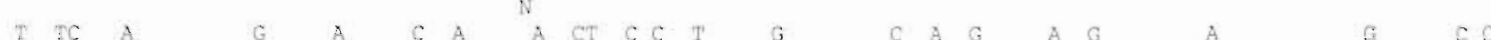
GAAGACAACAAGATATGGGCTAAAGTCTCCGCTGAAGTCATGACCCGTCTGTTGTTCGAGAAATTCAACAATCCTGAACTCTCTAAACACCTAATTAACACAGGCAAAAGTCACTTGGTT 6OO E D N K I W A K V S A E V M T R L L F E K F N N F E L S K H L I N T G K S H L V 200 Q $\mathrm{k}$

GAGAACACACAACATCCA

E N T Q H P

b)

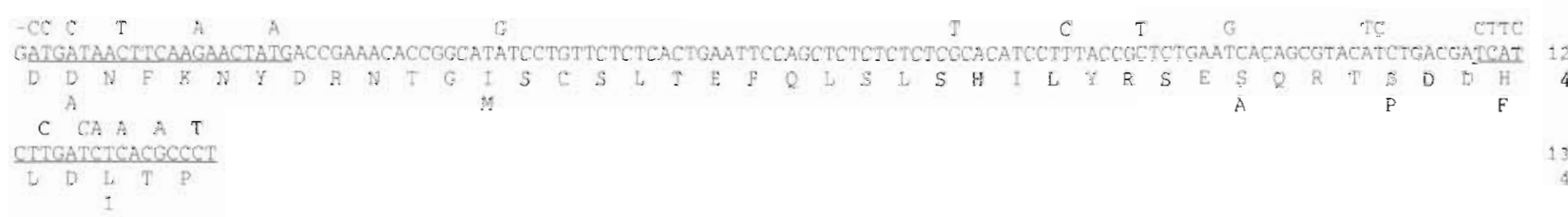

c)

$\begin{array}{ccccccccc}C & C & C & C & C & A & G & A & T\end{array}$ $\mathrm{L} K$ M D I F D Y T Y T C Y T K A H S F A L Q A C S T Y N F D I T P D N I C P E G A

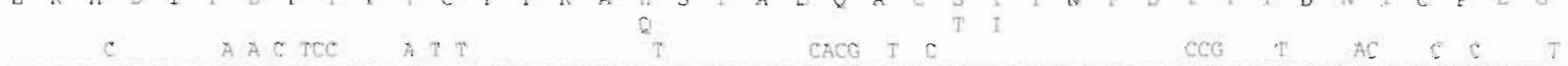
GTCTATGATTTCGAGACCTTTAGAATCGGCACTCGCGATCCOATCAAAGCGCTCAACGCCGTATHCTACTGTATCGACGTCACTGGTTCTTTTCTGGCCTCTCCATCTCATGTGCATCC 240 $\checkmark Y D F E$ E F R I G T R D P I K A L N A Y F Y C I E R H W F F G L S I S C A S BO

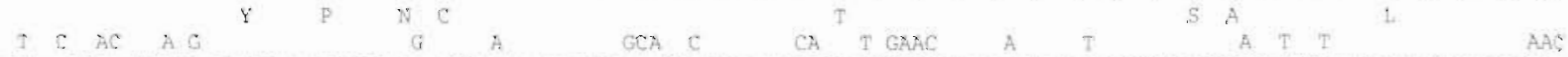
ATCHATCCTAATGCAAACATGACAATTCATCAATACAAGGAAGCATTCAACCTTTACACTAATGAACTTGCAACAGAGGTCACACTCAAACACCAGCCAACATTCGACTCCTATCTCTCA

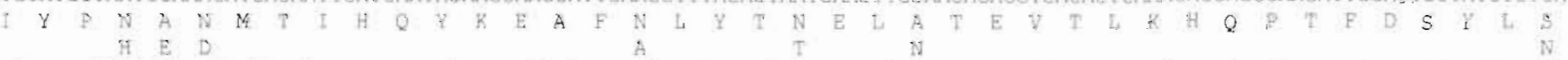
C. TGTC CA G T C T C C A G G T TTTATGCTCACAAAGGAACGCCATAACATCAACATCGACATTGGTACAGGCGCAAACACTTTCTACACCTCCTTCGACACAATCAACTCTGCTCCATGCACAGACGAACGTTACGAACAA

F M L T K E R H N I N I D I G T G A N T F Y I S F D T I U S A P G T D E R Y E E $\because \quad \mathrm{T}$ GCC G

GTCATGATAGGTGTCACTCGTCTCTACTACGCCTATCAGTATGATCGCGGTGACTTCCCTTGTAAATACACAGTCACACAAACACACATCAAATACCCAGTAATCGGCGATGTTGCTGTT.

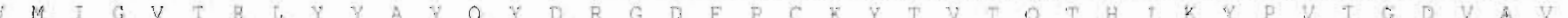

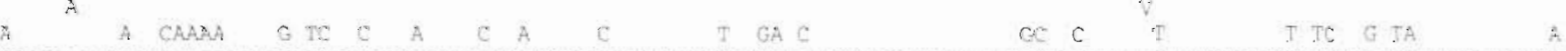
GAGCCTGAGAGTGTTCTTATCCCACATGTAACGGTTATCCGCCAGTTTACAGTGCCCTCGITICCATCCAGAAATTCACAACTTGGGCACGTCTCATGGGATATAACGTTCTCAAGCGC: 720 E P E E C S Y P T C N G Y P P V Y S A L V S I Q R E T F

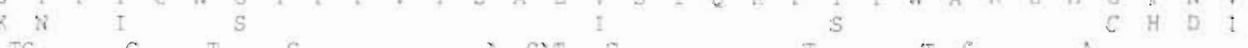

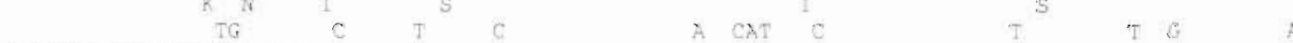

GTCTTCAATCACTGTCGCAACTGTGAACATCTCAACTGTAAGATCTCACGGCAGCTAGCGCGATTCAAGAATCCACTCTCCAACATCCAACCAGTCGCTTACACTAAACTACACGAAGAC BLD

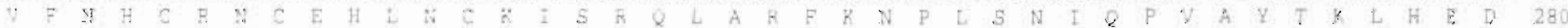
A C C C T A G C TA C T T C I G A A G CTGA T T CC CGTCACGTCATTCGTGATCGTCTCACACACATGGACTTCACATCAGGACAGGAATTCTATGCCGCTGAATTCATARAAGAGTTTAACGACATCGAGTTCACTACAACACACGGCGACAAG R H L I R D A L T H M D F T S G Q E F Y A A E F I K E E N D I E F T. T T. H G D K 320

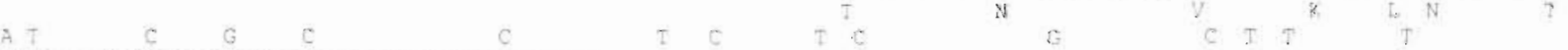
CTACACTTCAATCTCACACATCCTTATGACGCTCTCCTTGAACCTCTACTCCCTTCTAACACACTTGTCGGAAATCAGTAGCAGCATCAGGGGTCATCAGTGATCTAG

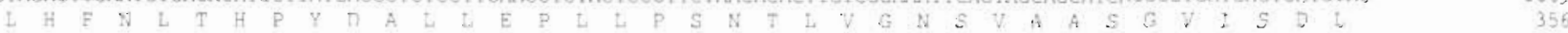

Fig. 2. Comparison of GAV ORF1b gene sequences with cognate regions of YHV including (a) a 577 nucleotide region amplified by RT-PCR with the primer pair GAV5-6, (b) a 135 nucleotide region reported by Wongteerasupaya et al. (1997) and (c) a 1068 nucleotide region of a sequence reported by Tang \& Lightner (1999). The nucleotide and deduced amino acid sequences of GAV are indicated with YHV nucleotide and amino acid differences indicated above and below, respectively. YHV nucleotides not known are indicated $(-)$. The positions of PCR primers in (a) GAV5 $\left(A^{1}=C^{20}\right)$, GAV6 (G $\left.{ }^{598}-A^{618}\right)$, GAV1 (A $\left.{ }^{230}-C^{251}\right)$ and $G A V 2$ $\left(C^{526}-C^{546}\right)$ and in (b) $10 F\left(C^{2}-G^{22}\right)$ and $144 R\left(C^{117}-T^{136}\right)$ are underlined 


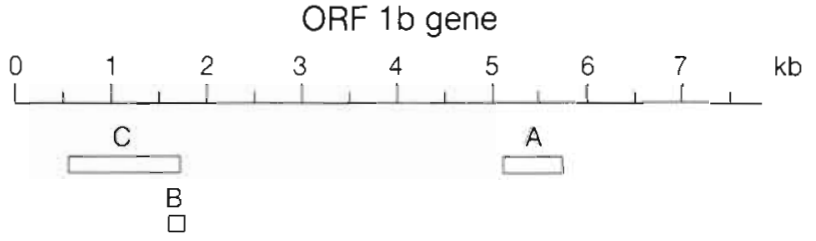

Fig. 3. Relative positions along the $\sim 7.8 \mathrm{~kb}$ GAV ORF1b gene of the 3 YHV regions used in sequence comparisons. Sequence identity values (nucleotide \%, amino acid \%) for the regions were (A) 577 nucleotide region $(85.1 \%, 95.8 \%)$, (B) 135 nucleotide region $(83.0 \%, 86.7 \%$ ) (Wongteerasupaya et al 1997) and (C) 1068 nucleotide region $(80.9 \%, 86.5 \%)$ (Tang \& Lightner 1999)

demiological investigations to trace possible virus sources responsible for disease episodes and to validate the origin of exotic viruses where incursions are suspected. As $\mathrm{YHV}$ primers $10 \mathrm{~F}$ and $144 \mathrm{R}$ fail to amplify GAV sequences, they may be suitable, in conjunction with GAV-specific primers, for the differential detection of yellow head-like viruses from Thailand and Australia. Ultimately however, sequence analysis of RT-PCR products generated with generic yellow head-like virus primers will provide a more useful tool for distinguishing between isolates from different geographical regions.

Acknowledgements. The authors thank the National Center for Genetic Engineering and Biotechnology of Thailand and the Thailand Research Fund for supporting part of this work.

\section{LITERATURE CITED}

Boonyaratpalin S, Supamattaya K, Kasornchandra J, Direkbusaracom S, Aekpanithanpong U, Cantanachookin C (1993) Non-occluded baculo-like virus, the causative agent of yellow-head disease in the black tiger shrimp (Penaeus monodon). Fish Pathol 28:103-109

Bredenbeek PJ, Pachuk CJ, Noten AF, Charite J, Luytjes W, Weiss SR, Spaan WJ (1990) The primary structure and expression of the polymerase gene of the coronavirus MHV-A59; a highly conserved polymerase is expressed by an efficient ribosomal frameshifting mechanism. Nucleic Acids Res 18:1825-1832

Chantanachookin C. Boonyaratpalin S, Kasornchandra J, Sataporn D, Ekpanithanpong U, Supamataya K, Sriuraira-

Editorial responsibility: Tim Flegel,

Bangkok, Thailand tana S, Flegel TW (1993) Histology and ultrastructure reveal a new granulomas-like virus in Penaeus monodon affected by yellow-head disease. Dis Aquat Org 17: $145-157$

Froussard $P$ (1992) A random-PCR method ( $\mathrm{PCCR}$ ) to construct whole cDNA library from low amounts of RNA. Nucleic Acids Res 20:2900

Lee HJ, Shiek CK, Gorbalenya AE, Koonin EV, La Monica N, Tuler J, Bagdzhadzhyan A, Lai MM (1991) The complete sequence ( 22 kilobases) of murine coronavirus gene 1 encoding the putative proteases and RNA polymerase Virology 180:567-582

Lightner DV, Redman RM, Poulos BT, Nunan LM, Mari JL, Hasson KW (1997) Risk of spread of penaeid shrimp viruses in the Americas by the international movement of live and frozen shrimp. Rev Sci Tech 16:146-160

Limsuwan C (1991) Handbook for cultivation of black tiger prawns. Tansetakit Co Ltd, Bangkok

Loh PC, Tapay LM, Lu Y, Nadala ECB Jr (1997) Viral pathogens of the penaeid shrimp. Adv Virus Res 48:263-312

Nadala ECB Jr, Tapay LM, Loh PC (1997) Yellow-head virus: a rhabdovirus-like pathogen of penaeid shrimp. Dis Aquat Org 31:141-146

Nunan LM, Poulos BT, Lightner DV (1998) The detection of white spot syndrome virus (WSSV) and yellow head virus (YHV) in imported commodity shrimp. Aquaculture 160 $19-30$

Poch O, Blumberg BM, Bougueleret L, Tordo N (1990) Sequence comparison of five polymerases (L proteins) of unsegmented negative-strand RNA viruses: theoretical assignment of functional domains. J Gen Virol 71:1153-1162

Sambrook J, Fritsch EF, Maniatis T (1989) In: Molecular cloning: a laboratory manual 2nd edn. Cold Spring Harbor Laboratory Press, USA

Spann KM, Vickers JE, Lester RJG (1995) Lymphoid organ virus of Penaeus monodon from Australia. Dis Aquat Org 23:127-134

Spann KM, Cowley JA, Walker PJ, Lester RJG (1997) A yellow-head-like virus from Penaeus monodon cultured in Australia. Dis Aquat Org 31:169-179

Tang KFJ, Lightner DV (1999) A yellow head virus gene probe: nucleotide sequence and application for in situ hybridization Dis Aquat Org 35:165-173

Wang CS, Tang KFJ, Kou GH, Chen SN (1996) Yellow head disease-like virus infection in Kuruma shrimp Penaeus japonicus cultured in Taiwan. Fish Pathol 31:177-182

Wongteerasupaya C. Sriurairatana S, Vickers JE, Akrajamorn A, Boonsaeng V, Panyim S, Tassanakajon A, Withyachumnarnjul B, Flegel TW (1995) Yellow-head virus of Penaeus monodon is an RNA virus. Dis Aquat Org 22:45-50

Wongteerasupaya $C$, Tongcheua $W$, Boonsaeng $V$, Panyim $S$, Tassanakajon A, Withyachumnarnkul B, Flegel TW (1997) Detection of yellow-head virus of Penaeus monodon by RT-PCR amplification. Dis Aquat Org 31:181-186

Submitted: November 11, 1998; Accepted: February 13, 1999 Proofs received from author(s): April 27, 1999 